\title{
The Influence of Fish Ponds on Fish Assemblages of Adjacent Watercourses
}

\author{
Bartosz Bojarski*, Mateusz Jakubiak², Pawel Szczerbik ${ }^{3}$, Michał Bień4, \\ Artur Klaczak ${ }^{5}$, Tomasz Stański ${ }^{6}$, Małgorzata Witeska ${ }^{7}$
}

'Institute of Ichthyobiology and Aquaculture in Gołysz, Polish Academy of Sciences, Kalinowa 2, Zaborze, 43-520 Chybie, Poland

${ }^{2}$ AGH University of Science and Technology, Faculty of Mining Surveying and Environmental Engineering, Department of Environmental Management and Protection, Mickiewicza 30, 30-059 Krakow, Poland

${ }^{3}$ Center of Experimental and Innovative Medicine, University of Agriculture in Krakow, Mickiewicza 24/28, 30-059 Krakow, Poland

${ }^{4}$ Kielce District of Polish Angling Association (PZW), Warszawska 34a/31, 25-313 Kielce, Poland

${ }^{5}$ Department of Nutrition, Animal Biotechnology and Fisheries, Faculty of Animal Science, University of Agriculture in Krakow, Mickiewicza 24/28, 30-059 Krakow, Poland

${ }^{6}$ Siedlce University of Natural Sciences and Humanities, Faculty of Exact and Natural Sciences, Prusa 14, 08-110 Siedlce, Poland

${ }^{7}$ Siedlce University of Natural Sciences and Humanities, Faculty of Exact and Natural Sciences, Institute of Biological Sciences, Prusa 14, 08-110 Siedlce, Poland

Received: 7 June 2021

Accepted: 27 July 2021

\begin{abstract}
Carp ponds are inhabited mainly by aquaculture fishes but also harbor alien unwanted species that may threaten native fish assemblages when escape from the ponds. In the current study fish communities of inflow and outflow watercourses (canals) of the fish ponds in two typical common carp fish farms were studied. The results revealed that outflow canals contained cultured fish that escaped from the ponds. Invasive alien species (IAS) were also observed e.g. stone moroko (Pseudorasbora parva) and Prussian carp (Carasus gibelio). On the other hand, the canals harbored valuable endangered fish e.g. common nase (Chondrostoma nasus) or brown trout (Salmo trutta) and protected species stone loach (Barbatula barbatula). We have shown that fish ponds affect neighboring watercourses, and that the canals themselves can contribute to the species richness of ichthyofauna. Therefore, monitoring of these ecosystems should be carried out on a regular basis.
\end{abstract}

Keywords: aquaculture, carp ponds, fish communities, invasive alien species

*e-mail: bbojarski@o2.pl, bartosz.bojarski@golysz.pan.pl 


\section{Introduction}

Aquaculture industry is a rapidly developing food sector, and thus its impact on natural environment is an important issue [1]. Exponential growth of human population brought about a need to search for additional sources of animal protein and in many countries fish meat actually is main source of such protein [2, 3]. Aquaculture is also an important source of income for millions of people [4]. Freshwater aquaculture is growing faster than mariculture and in 2016 freshwater fish comprised about 65 percent of total aquaculture production [1].

The effects of aquaculture facilities on environment depend among others on farming intensity. Aquaculture industry includes small size and low-input farms operated by individual farmers, comprising several ponds, as well as large, highly industrialized farms, requiring high input and operated sometimes by transnational corporations [4-7]. The intensity of fish production has both economical and ecological implications. Generally, the more intensive production system, the higher environmental impact of a farm. Extensive, low density and low yield fish rearing based on natural food (phytoplankton, zooplankton, bottom-dwelling invertebrates and small fish), with occasional fertilization to increase primary production exert low impact on adjacent natural ecosystems. Production intensification to increase fish yield brings about increase of labor and cost input (commercial feed, chemicals and equipment), and of course involves high environmental impact [7-9]. Semiintensive culture is an intermediate trade-off solution that allows to increase fish production above the level based exclusively on natural food. In such systems fish densities are higher than in extensive culture and their diet is supplemented with feed [7, 9-10]. Increase in rearing intensity involves an increase in the amount of additional feed which affects the water contamination [11, 12]. Both, extensive and semi-intensive management systems, are typical for European carp ponds aquaculture [13, 14]. Aquaculture pond effluents rich in nutrients pose a threat to natural aquatic ecosystems causing eutrophication [15-17]. Moreover, intensive aquaculture is a source of other dangerous effluents such as medications, disinfectants and antifoulants. Another possible danger posed by aquaculture facilities to the natural water bodies is escape of cultured organisms and invading natural ecosystems. Particularly, introduction of new alien species may result in considerable disturbances in natural assemblages, adversely affect ecosystem stability and reduce biodiversity. Interactions of alien species with native ones include competition and predation, abiotic disturbances (e.g. alterations in nutrient turnover, increase in water turbidity etc.) and introduction of new diseases. This may result in reduction or even extinction of native fishes, shellfish, vegetation or waterfowl [18-21].
Freshwater inland fish farms (excluding closed recirculating systems) are complex hydrological systems connected with the adjacent natural watercourses. They are usually set up near rivers that supply water to the ponds. Besides the ponds of various size and depth for fish farming, systems include networks of channels (ditches). Usually water is supplied by main inflow channel connecting a farm with a river and carries fresh water to the ponds. Effluents are carried by outflow canals back to the river. Therefore, aquaculture in particular affects outflow canals. The ponds are connected with canals through sluices that allow water level control in the ponds [22]. Hydrological connection of a fish farm and adjacent surface waters directly affect mutual relationships of natural and artificial ecosystems (pollutants that can cause eutrophication, breeding species, invasive species, parasites and diseases, chemicals used in aquaculture) [13, 14, 16, 18, 23].

Carps, barbels and other cyprinids are one of the major caught and farmed inland fish species groups. The demand for these fish shows a continuous increase. The common carp (Cyprinus carpio), in terms of production, is in $4^{\text {th }}$ place among species produced in the world aquaculture. Its global production has increased more than $25 \%$ in the last 10 years and exceeded 4 million tons in 2018 [24]. Carp is the oldest aquaculture fish species in Europe. In some regions of Poland and Germany, it was already farmed around 900 years ago $[14,25]$. Many centuries of traditional carp farming influenced the culture and landscape of those regions [26, 27]. Common carp is currently the most widely farmed pond fish in Central and Eastern Europe. In the European Union, $80 \%$ of carp production comes from four countries: Czech Republic, Poland, Hungary and Germany $[25,27]$.

Typical carp ponds are shallow, most often artificial, specially designed for fish farming, water reservoirs with a very diverse surface area (from less than a hectare to even several hundred hectares) [28]. Ponds were built mainly in wetlands, in areas with high groundwater levels and near rivers. The inflow and outflow canals system allows to fill a reservoir with water from a river and to drain it in order to harvest the fish [28, 29]. Carp ponds are also used for aquaculture of other fish, such as crucian carp (Carassius carassius), tench (Tinca tinca), grass carp (Ctenopharyngodon idella), silver carp (Hypophthalmichthys molitrix), as well as predators like northern pike (Esox lucius), pikeperch (Sander lucioperca), wels catfish (Silurus glanis) and European perch (Perca fluviatilis). The polyculture is a common practice in European carp pond farming, especially in organic aquaculture [30].

The importance of carp ponds in the Central and Eastern Europe is constantly increasing with the growing demand for freshwater fish. Besides fish production, carp ponds provide a number of ecosystem services: water retention, nutrient reclamation, green biomass production, biodiversity conservation, oxygen production, microclimate regulation, landscaping being 


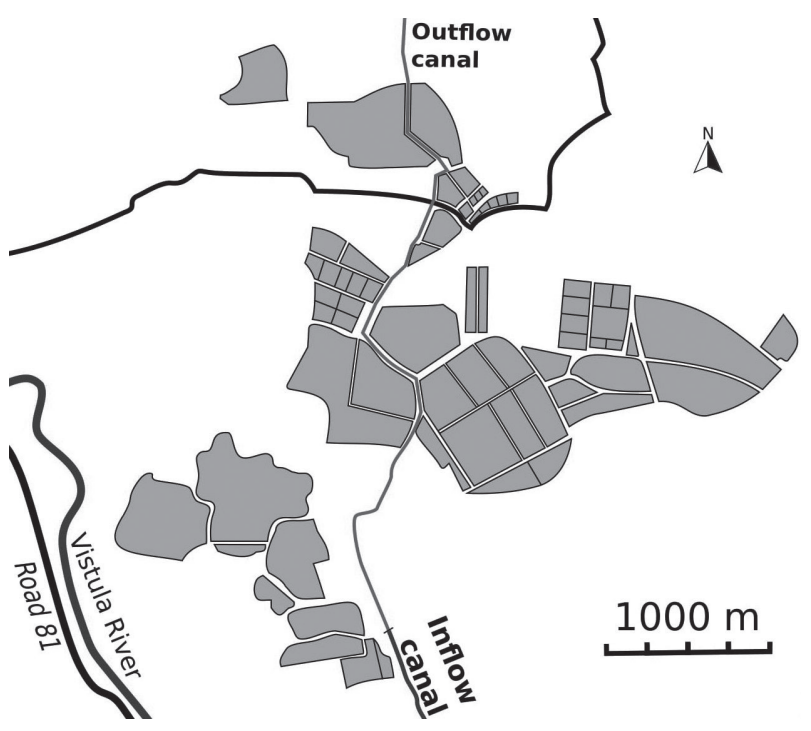

Fig. 1. Gołysz Fish Farm scheme.

the most important ones [31]. Moreover, areas of fish farms can be a place for leisure, recreation and contact with nature [27, 29]. However, despite the economic importance and providing many ecosystem services, the correlations between the fauna and flora of carp ponds and the surrounding environment are still poorly researched.

The influence of freshwater fish production on surface water ecosystems seems to depend on the production technology. Contamination, nutrients supplying and releasing of farmed fish to the watercourses are a potential consequences of production technologies. Detection of farmed fish in adjacent ecosystems may help to select more appropriate technical devices to limit the amount of escaping fish. The first aim of the present study was to determine the species composition of fish assemblages of the watercourses being a part of hydrological network of chosen carp pond farms. Another objective was to compare the fish abundance, species richness, and species diversity (expressed by the Shannon diversity index) between inflow and outflow canals of two analysed fish farms, and to assess how these parameters change over time, i.e., in sampling months during the study period. The present study was also an attempt to evaluate the influence of fish pond culture on diversity and abundance of fish assemblages in the outlet canals. To our knowledge, only one scientific article that relates directly to that subject has been published so far [18], so it can be considered unrecognized.

\section{Material and Methods}

The study was carried out in the canals of two fish farms with semi-intensive aquaculture of common carp and additional species: Institute of Ichthyobiology and Aquaculture of the Polish Academy of Sciences in Gołysz (Fig. 1) and Experimental Fisheries Station of the Department of Ichtiobiology and Fisheries, University of Agriculture in Krakow (Fig. 2). Fish were sampled from two inflow and three outflow canals (Table 1). Gołysz Fish Farm is situated in Southern Poland (49 $\left.52^{\prime} 10^{\prime \prime} \mathrm{N} 18^{\circ} 47^{\prime} 50^{\prime \prime} \mathrm{E}\right)$. It includes rearing and experimental ponds of about 900 ha water table area. Rearing and breeding of common carp is a primary activity but also other species are cultured such as grass carp, silver carp, bighead carp (Hypophthalmichthys nobilis), wels catfish, tench, northern pike, pike-perch, crucian carp, Prussian carp (Carassius gibelio) and roach (Rutilus rutilus). Inflow channel supplying water to the ponds is fed by Vistula River. Directly ahead the ponds water flow is controlled using a vertical lift gate which allows redirecting of water to the channel supplying a dense network of inflow canals feeding each fish pond. Fish were sampled from the section of channel preceding the gate (inflow canal). Main

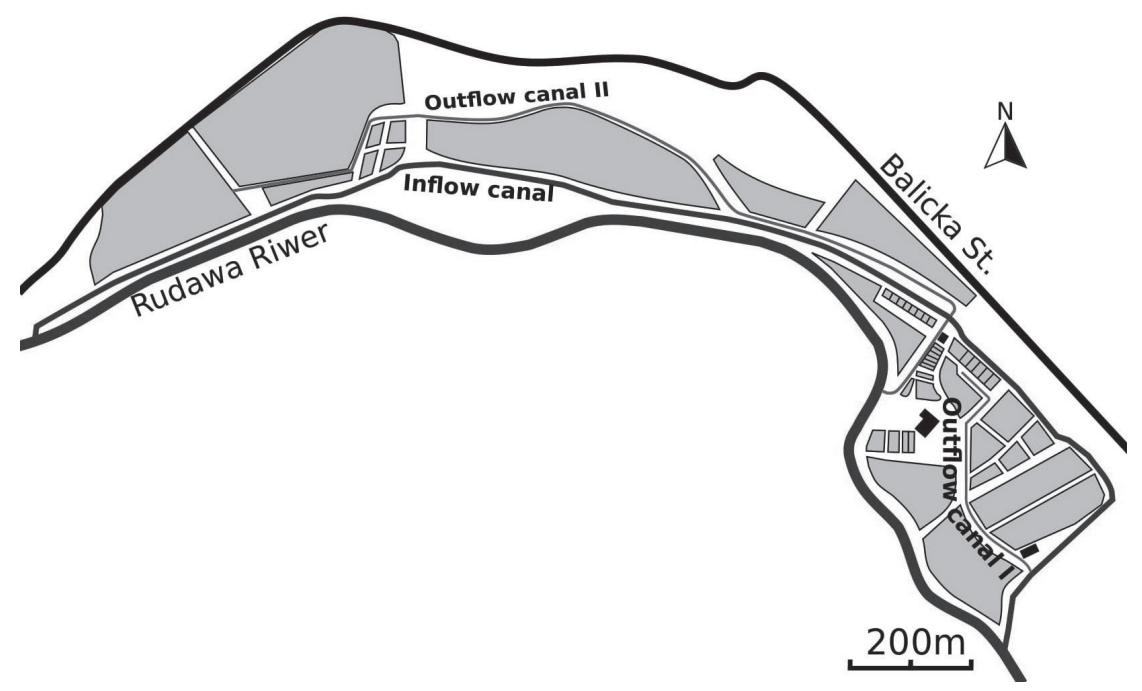

Fig. 2. Krakow Fish Farm scheme. 
Table 1. Characteristics of the studied canals in May-Sept. 2018.

\begin{tabular}{|c|c|c|c|c|}
\hline Name & Water supply & Maximum depth $[\mathrm{cm}]$ & Maximum water table width [cm] & Current velocity [m³ $/ \mathrm{s}]$ \\
\hline Inflow Gołysz & Vistula River & $54-86$ & $320-440$ & $0.16-0.42$ \\
\hline Outflow Gołysz & Ponds & $39-90$ & $210-370$ & $0.01-0.36$ \\
\hline Inflow Krakow & Rudawa River & $61-122$ & $330-430$ & $0.07-0.57$ \\
\hline Outflow I Krakow & Ponds & $20-37$ & $90-145$ & $0.02-0.06$ \\
\hline Outflow II Krakow & Ponds & $20-60$ & $90-150$ & $0.07-0.16$ \\
\hline
\end{tabular}

channel then flows through the farm area and receives outflow water from the ponds (outflow canal). Fish were sampled from the section of channel situated downstream from the last pond. Fish farm of the University of Agriculture in Krakow is a complex of 51 rearing and experimental ponds of about 26 ha water table area. It is situated in the North-Western suburb of Krakow (5005'06”N 19॰50'25”E) [32]. Common carp rearing and breeding is a main activity but also other fish species are cultured such as rainbow trout (Oncorhynchus mykiss), sterlet sturgeon (Acipenser ruthenus), grass carp, silver carp, bighead carp, wels catfish, pike-perch, northern pike, crucian carp and Prussian carp. The fish were sampled from the inflow canal providing water from Rudawa River to the fish ponds, and in the end sections of two outflow canals I and II carrying water discharged from the ponds back to the Rudawa River. Fish catches in both fish farms were performed once a month, from May to September 2018.

Fish were sampled using electrofishing method with stationary device EL62 IIGI (Hans Grassl, Germany) powered using $3.5 \mathrm{~kW}$ generator. Pulsatory direct current of $70 \mathrm{~Hz}$ pulse frequency, voltage $200-400 \mathrm{~V}$

Table 2. Number $(\mathrm{N})$ and percentage (\%) of various fish species captured in the inflow and outflow canals of Gołysz and Krakow Fish Farms ('-' means 'not detected').

\begin{tabular}{|c|c|c|c|c|c|c|c|c|c|c|}
\hline \multirow{2}{*}{ Species } & \multicolumn{2}{|c|}{ Inflow Gołysz } & \multicolumn{2}{|c|}{ Outflow Gołysz } & \multicolumn{2}{|c|}{ Inflow Krakow } & \multicolumn{2}{|c|}{ Outflow I Krakow } & \multicolumn{2}{|c|}{ Outflow II Krakow } \\
\hline & $\mathrm{N}$ & $\%$ & $\mathrm{~N}$ & $\%$ & $\mathrm{~N}$ & $\%$ & $\mathrm{~N}$ & $\%$ & $\mathrm{~N}$ & $\%$ \\
\hline Alburnus alburnus & 1 & 0.2 & - & - & - & - & - & - & - & - \\
\hline Barbatula barbatula & 22 & 4.3 & - & - & 23 & 11.2 & 6 & 2.4 & 31 & 39.2 \\
\hline Barbus barbus & 3 & 0.6 & - & - & - & - & - & - & - & - \\
\hline Carassius carassius & - & - & - & - & - & - & 5 & 2.0 & - & - \\
\hline Carassius gibelio & - & - & 55 & 3.3 & 17 & 8.3 & 7 & 2.8 & 2 & 2.5 \\
\hline Chondrostoma nasus & - & - & 3 & 0.2 & - & - & - & - & - & - \\
\hline Cyprinus carpio & 1 & 0.2 & 32 & 1.9 & - & - & - & - & 9 & 11.4 \\
\hline Esox lucius & - & - & 13 & 0.8 & - & - & 33 & 13.1 & 1 & 1.3 \\
\hline Gasterosteus aculeatus & - & - & - & - & 13 & 6.3 & 8 & 3.2 & 2 & 2.5 \\
\hline Gobio gobio & 50 & 9.8 & 197 & 12.0 & 129 & 62.9 & 169 & 67.1 & 27 & 34.2 \\
\hline Gymnocephalus cernua & - & - & 1 & 0.1 & - & - & - & - & - & - \\
\hline Leuciscus leuciscus & 1 & 0.2 & 5 & 0.3 & - & - & - & - & - & - \\
\hline Perca fluviatilis & 123 & 24.1 & 136 & 8.3 & - & - & - & - & - & - \\
\hline Pseudorasbora parva & 8 & 1.6 & 577 & 35.1 & - & - & 2 & 0.8 & - & - \\
\hline Rutilus rutilus & 27 & 5.3 & 448 & 27.2 & 1 & 0.5 & 2 & 0.8 & - & - \\
\hline Salmo trutta & - & - & - & - & 22 & 10.7 & - & - & 7 & 8.9 \\
\hline Sander lucioperca & - & - & 1 & 0.1 & - & - & - & - & - & - \\
\hline Squalius cephalus & 273 & 53.4 & 176 & 10.7 & - & - & 18 & 7.1 & - & - \\
\hline Tinca tinca & 2 & 0.4 & 2 & 0.1 & - & - & 2 & 0.8 & - & - \\
\hline Total & 511 & 100 & 1646 & 100 & 205 & 100 & 252 & 100 & 79 & 100 \\
\hline
\end{tabular}


and amperage 2.0-3.5 A was generated. Each sampling site was sampled along zigzag transect, wading $90 \mathrm{~m}$ upstream.

In each sample number of caught individuals, number of species and Shannon diversity index were calculated. Shannon diversity index was calculated according to the formula:

$$
\mathrm{H}^{\prime}=-\Sigma \text { pi ln pi, }
$$

...where pi is the proportion of individuals belonging to species i.

To evaluate the significance of differences in number of individuals, number of species and Shannon diversity index values between (Gołysz) or among (Krakow) the canals, U Mann-Whitney (Gołysz) and KruskalWallis with post hoc Dunn (Krakow) tests were applied. To compare percentage of various fish species in the canals, G test was performed, separately for each fish farm. Statistica 12.0 software was used for statistical analysis, the differences were considered significant at $\mathrm{p}<0.05$.

\section{Results and Discussion}

Fish catches performed in Gołysz Fish Farm yielded 2157 fish of 16 species, including 511 individuals of 11 species in the inflow canal and 1646 individuals of 13 species in the outflow canal (Table 2). The most abundant species caught in the inflow canal were chub (Squalius cephalus) (53.4\%) and European perch (24.1\%), while in the outflow canal stone moroko (Pseudorasbora parva) (35.1\%) and roach (27.2\%) (Table 2). The two studied canals significantly differed in contribution of various species in fish assemblages ( $\mathrm{G}$ test, $\mathrm{G}=108.44 ; \mathrm{p}<0.001$, df $=15$ ). No significant differences were found in respect of the number of individuals and species richness between both canals ( $U$

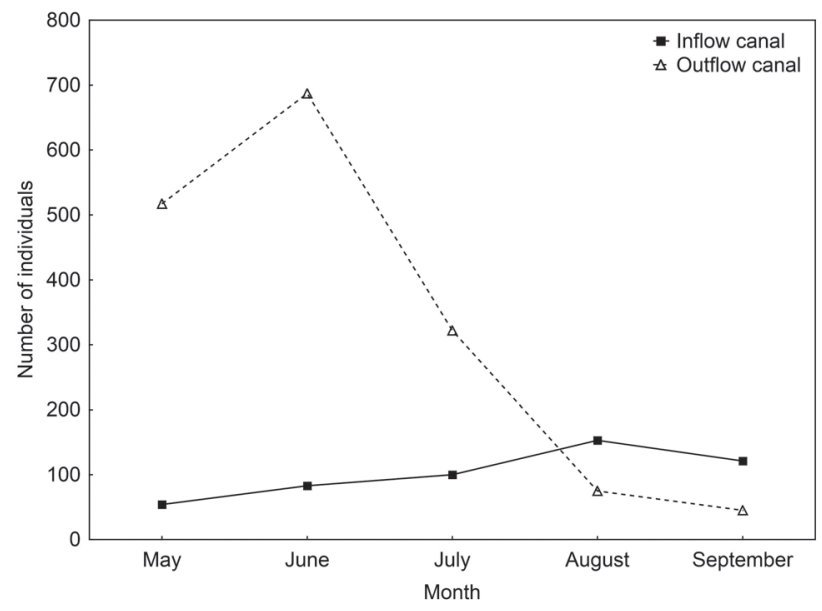

Fig. 3. Number of fish individuals captured in each month in the inflow and outflow canals in Gołysz Fish Farm.

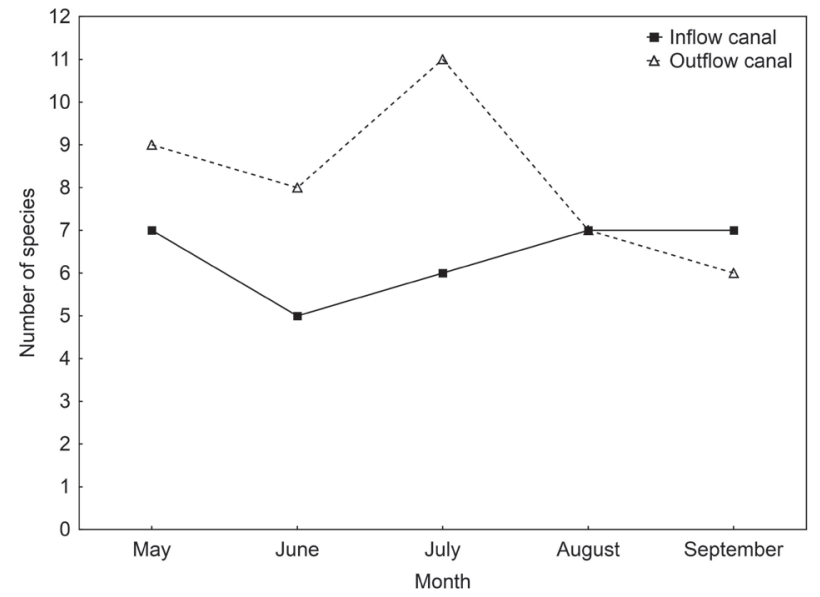

Fig. 4. Number of fish species captured in each month in the inflow and outflow canals in Gołysz Fish Farm.

Mann-Whitney test, $\mathrm{p}>0.05$ ) despite the higher number of individuals and species recorded in the outflow canal during the first three months of monitoring (Fig. 3 and 4). The value of Shannon diversity index was significantly higher in the outflow canal compared to the inflow canal ( $\mathrm{U}$ Mann-Whitney test, $\mathrm{p}=0.009$, Fig. 5) and this difference was visible in all months of monitoring (Fig. 6).

In the Krakow Fish Farm, a total of 536 fish belonging to 12 species were captured, including 205 individuals of 6 species in the inflow canal, 252 individuals of 10 species in the outflow canal I and 79 individuals of 7 species in the outflow canal II (Table 2). Gudgeon (Gobio gobio) was the most abundant species both in the inflow canal and outflow canal I (62.9\% and $67.2 \%$, respectively), while in the outflow canal II stone loach (Barbatula barbatula) (39.2\%) and gudgeon (34.2\%) predominated (Table 2). Significant differences in the percentage contribution of various fish species were found between all pairs of

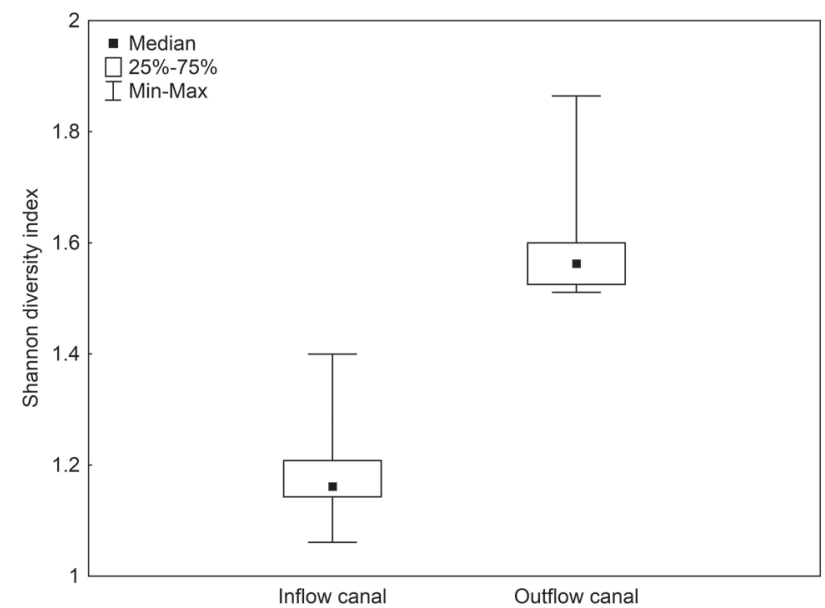

Fig. 5. Species diversity (as Shannon diversity index values) in the inflow and outflow canals in Gołysz Fish Farm. 
canals: inflow and outflow I ( $G$ test, $G=58,28 ; p<0.001$; $\mathrm{df}=11$ ), inflow and outflow II ( $\mathrm{G}$ test, $\mathrm{G}=48,44$; $\mathrm{p}<0.001$; $\mathrm{df}=11$ ) and outflow I and outflow II (G test, $\mathrm{G}=105,79 ; \mathrm{p}<0.001 ; \mathrm{df}=11)$. The numbers of captured fish and Shannon diversity index values considerably varied over time (Fig. 7 and 8) but no statistically significant differences in the values of these parameters among the canals occurred (Kruskal-Wallis test, $\mathrm{p}>0.05)$. However, significant differences in the number of species were observed (Kruskal-Wallis test, $\left.\mathrm{H}_{2,15}=6.68, \mathrm{p}=0.035\right)$. The significantly higher number of species was captured in the outflow canal I compared to canal II (post hoc Dunn test $p=0.036$, Fig. 9), and the differences occurred in each month of the study (Fig. 10).

Fish pond complexes belong to small water retention reservoirs that not only play an important role in water and landscape management but also are habitat of aquatic and amphibious organisms

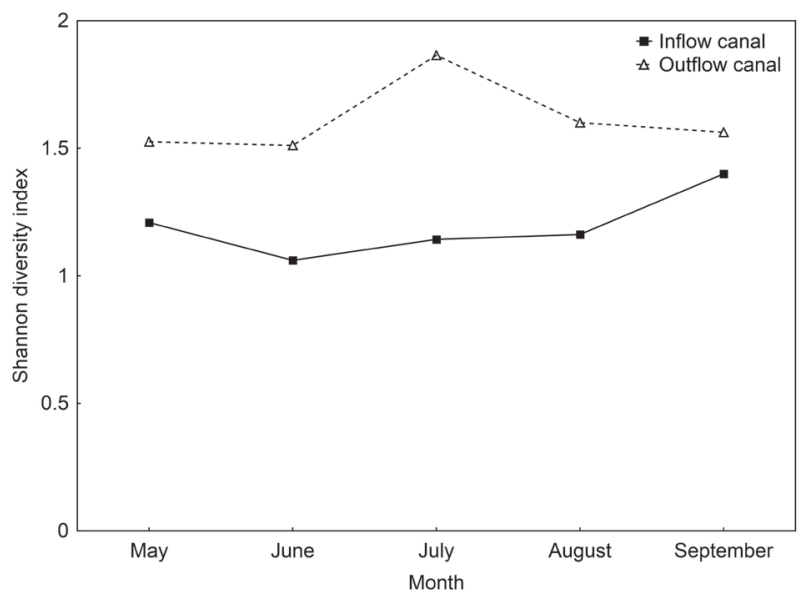

Fig. 6. Species diversity (as Shannon diversity index values) in each month in the inflow and outflow canals in Gołysz Fish Farm.

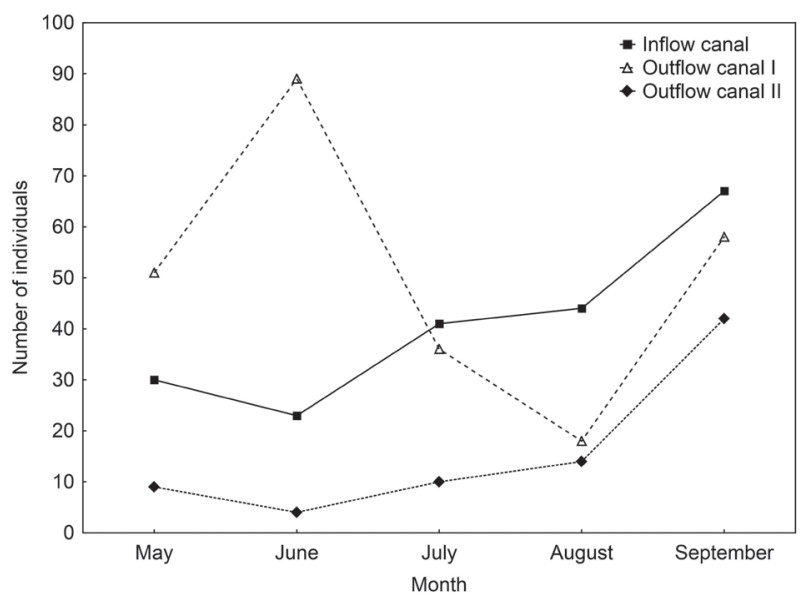

Fig. 7. Number of fish individuals captured in each month in the inflow and outflow canals in Krakow Fish Farm.

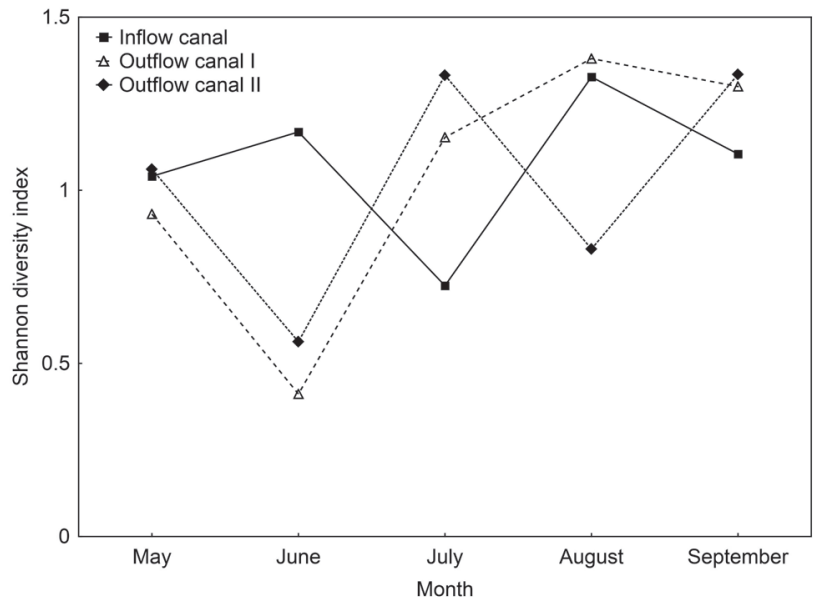

Fig. 8. Species diversity (as Shannon diversity index values) in each month in the inflow and outflow canals in Krakow Fish Farm.

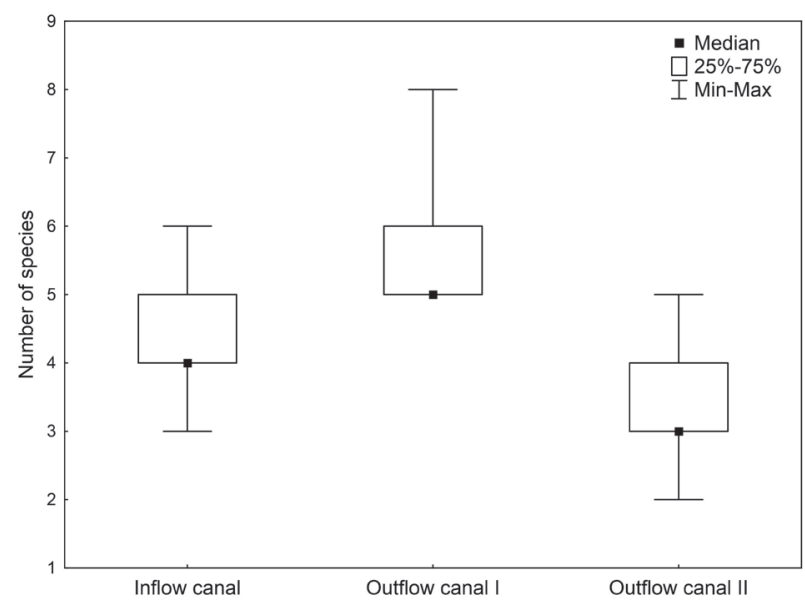

Fig. 9. Number of fish species captured in the inflow and outflow canals in Krakow Fish Farm.

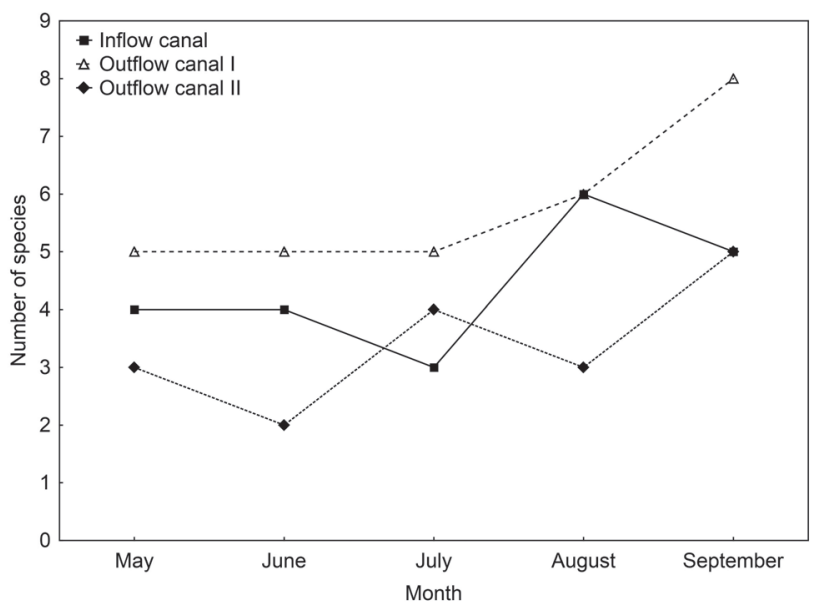

Fig. 10. Number of fish species captured in each month in the inflow and outflow canals in Krakow Fish Farm. 
[33]. Despite the importance of fish ponds for nature protection, very little studies of these ecosystems has been performed [34]. In particular, little attention is paid to ecological role of small watercourses - canals being a part of hydrotechnical network of fish farms. However, these ecosystems, despite high variability of environmental conditions, may play an important role in maintaining biodiversity [32]. The inflow and outflow canals of the fish farms may host abundant fish assemblages, often very diverse. They sometimes harbor valuable fish species such as brown trout (Salmo trutta) or weatherfish (Misgurnus fossilis) [35]. In the current study, 19 fish species belonging to 6 families (Cyprinidae, Percidae, Gasterosteidae, Salmonidae, Esocidae, and Nemacheilidae) were observed which indicates high biodiversity of the studied ecosystems. Among the fish species found, a few belonging to high categories of threat in Poland were observed (according to Witkowski et al. [36]): one endangered (EN): common nase (Chondrostoma nasus), one vulnerable (VU): barbel (Barbus barbus), two near threatened (NT): common dace (Leuciscus leuciscus) and crucian carp and one conservation dependent (CD) species: brown trout. Also, one strictly protected (in Poland) species was found - stone loach.

In the case of Gołysz ponds, the outflow canal showed significantly higher species diversity (as Shannon diversity index value) compared to the inflow. Outflow canal contained numerous cultured fish: common carp, Prussian carp, roach and northern pike that were also present in small numbers in the inflow. This indicates considerable effect of fish ponds on fish assemblages of adjacent aquatic ecosystems. In the outflow canal an invasive alien species (IAS) stone moroko was also very numerous. It is not a cultured species but may reproduce in fish ponds and invade natural waters [37]. In the outflow canal Prussian carp was also present, another IAS [38]. Both species are of Asian origin [39]. It is well known that pond aquaculture represent a major vector for the dispersion of alien fish species [40]. According to Musil et al. [18], pond canals can be an important reservoir site of survival and potential subsequent spreading of some undesirable alien fishes. The canals are always filled with water and thus the fish may survive in them when the ponds are drained. Increase in the number of fish in the outflow canal compared to the inflow might have also resulted from nutrient supply from the ponds [41] and increase in natural food abundance. Stone moroko and Prussian carp were found also in the hydrological network of Krakow Fish Farm, however their numbers were lower compared to Gołysz. These species were also observed in Krakow Fish Farm in 2011-2013 [32, 35]. On the other hand, alien and invasive Chinese sleeper (Perccottus glenii) found in 2007 by Nowak et al. [42] was not observed in the current study.

In the Krakow Fish Farm no significant differences were observed in the number of captured fish, number of species or Shannon diversity index values between the inflow and both outflow canals which suggests little effect of fish ponds on the adjacent watercourses. On the other hand, similarly as in Gołysz, cultured fishes were present in the outflow canals (northern pike, common carp and crucian carp). These species were absent from the inflow and thus it is supposed that they escaped from the ponds. Moreover, studies carried out in Krakow Fish Farm in 2011-2013 also revealed the presence of common carp in the outflow canal I [32, 35]. Chemical analysis of Krakow Fish Farm water [23] revealed no nutrient input from the ponds - concentrations of phosphate, nitrite nitrogen and nitrate nitrogen in the ponds decreased by $80-95 \%$ compared to the inflowing water which may explain the lack of significant increase in fish abundance in the outflow canal. However, the results obtained from both fish farms confirmed that fish ponds may be a source of cultured fish species to the adjacent canals, and then probably also to the natural waters.

\section{Conclusions}

Undoubtedly, inflow and outflow canals of pond fish farms are important ecosystems harboring numerous fish species, both valuable and unwanted invasive ones, often fugitives from the ponds. The influence of ponds on fish assemblages of the recipient watercourses may be different. It is probably related to the type of farm, its size, system of culture, management schedule, security facilities preventing fish escape, and last but not least - awareness and solicitude of the staff. Therefore, monitoring of the effects of fish ponds on the adjacent watercourses is an important environmental issue and should be carried out in pond fish farms of different aquaculture profile and located in different areas.

\section{Conflict of Interest}

The authors declare no conflict of interest

\section{References}

1. FAO. The state of world fisheries and aquaculture. Meeting the sustainable development goals. Rome, 2018.

2. TOUFIQUE K.A., BELTON B. Is aquaculture pro-poor? Empirical evidence of impacts on fish consumption in Bangladesh. World Develop. 64, 609, 2014.

3. BENE C., BARANGE M., SUBASINGHE R., PINSTRUPANDERSEN P., MERINO G., HEMRE G. I., WILLIAMS M. Feeding 9 billion by 2050 - Putting fish back on the menu. Food Secur. 7 (2), 261, 2015.

4. WATSON J.R., ARMERIN F., KLINGER D.H., BELTON B. Resilience through risk management: cooperative insurance in small-holder aquaculture systems. Heliyon $\mathbf{4}$ (9), e00799, 2018.

5. BOSTOCK J., MCANDREW B., RICHARDS R., JAUNCEY K., TELFER T., LORENZEN K., LITTLE D., ROSS L., HANDISYDE N., GATWARD I., CORNER R. 
Aquaculture: global status and trends. Philos. Transac. Royal Soc. B: Biol. Sci. 365 (1554), 2897, 2010.

6. LITTLE D.C., NEWTON R.W., BEVERIDGE M.C.M. Aquaculture: a rapidly growing and significant source of sustainable food? Status, transitions and potential. Proc. Nutr. Soc. 75 (3), 274, 2016.

7. OTTINGER M., CLAUSS K., KUENZER C. Aquaculture: relevance, distribution, impacts and spatial assessments a review. Ocean Coastal Manag. 119, 244, 2016.

8. HENRIKSSON P.J.G., BELTON B., MURSHEDE-JAHAN K., RICO A. Measuring the potential for sustainable intensification of aquaculture in Bangladesh using life cycle assessment. Proc. Nation. Acad. Sci. 115 (12), 2958, 2018.

9. DAUDA A.B., AJADIB A., TOLA-FABUNMIC A.S., AKINWOLE A.O. Waste production in aquaculture: Sources, components and managements in different culture systems. Aquacult. Fisher. 4 (3) 81, 2019.

10. 10. DAUDA A.B., IBRAHIM H.I., BICHI A.H., TOLAFABUNMI A.S. Assessment of fish farming practices, operations, water resource management and profitability in Katsina state, Nigeria. J. Northeast Agric. Univ. 24 (4), 89, 2017.

11. MARTINS C.I.M., EDING E.H., VERDEGEM M.C.J., HEINSBROEK L.T.N., SCHNEIDER O., BLANCHETON J.P., ROQUE D'ORBCASTEL E., VERRETH J.A.J. New developments in recirculating aquaculture systems in Europe: A perspective on environmental sustainability. Aquacult. Eng. 43 (3), 83, 2010.

12. AKINWOLE A.O., DAUDA A.B., OLOLADE A.O. Haematological response of Clarias gariepinus juveniles reared in treated wastewater after waste solids removal using alum or Moringa oleifera seed powder. Int. J. Aquacult. 6, 1, 2016.

13. VSETICKOVA L., ADAMEK Z., ROZKOSNY M., SEDLACEK P. Effects of semi-intensive carp pond farming on discharged water quality. Acta Ichthyol. Piscat. 42 (3) 223, 2012

14. BIERMANN G., GEIST J. Life cycle assessment of common carp (Cyprinus carpio L.) - A comparison of the environmental impacts of conventional and organic carp aquaculture in Germany. Aquacult. 501, 404, 2019.

15. ZHOU H.D., JIANG C.L., ZHU L.Q., WANG X.W., HU X.Q., CHENG J.Y., XIE M.H. Impact of pond and fence aquaculture on reservoir environment. Water Sci. Eng. 4 (1), 92, 2011

16. RACZYŃSKA M., MACHULA S., CHOIŃSKI A., SOBKOWIAK L. Influence of the fish pond aquaculture effluent discharge on abiotic environmental factors of selected rivers in Northwest Poland. Acta Ecol. Sin. 32 (3), 160, 2012.

17. XU Z., BOYD C.E. Reducing the monitoring parameters of fish pond water quality. Aquacult. 465, 359, 2016.

18. MUSIL J., ADAMEK Z., BARANYI C. Seasonal dynamics of fish assemblage in a pond canal. Aquacult. Int. 15 (3), 217, 2007.

19. SASS G.G., HINZ C., ERICKSON A.C., MCCLELLAND N.N., MCCLELLAND M. A., EPIFANIO J.M. Invasive bighead and silver carp effects on zooplankton communities in the Illinois River, Illinois, USA. J. Great Lakes Res. 40 (4), 911, 2014.

20. LODGE D.M., SIMONIN P.W., BURGIEL S.W., KELLER R.P., BOSSENBROEK J.M., JERDE C.L., KRAMER A.M., RUTHERFORD E.S., BARNES M.A., WITTMANN M.E., CHADDERTON W.L., APRIESNIG J.L., BELETSKY D., COOKE R.M., DRAKE J.M., EGAN
C.P., FINNOFF D.C., GANTZ C.A., GREY E.K., HOFF M.H., HOWETH J.G., JENSEN R.A., LARSON E.R., MANDRAK N.E., MASON D.M., MARTINEZ F.A. NEWCOMB T.J., ROTHLISBERGER D.J., TUCKER A.J., WARZINIACK T.W., ZHANG H. Risk analysis and bioeconomics of invasive species to inform policy and management. Ann. Rev. Environ. Res. 41, 453, 2016.

21. ZHANG H., RUTHERFORD E.S., MASON D.M., BRECK J.T., WITTMANN M.E., COOKE R.M., LODGE D.M., ROTHLISBERGER J.D., ZHU H., JOHNSON T.B. Forecasting the impacts of silver and bighead carp on the Lake Erie food web. Transac. Amer. Fisher. Soc. 145 (1), 136, 2016.

22. BALUYUT E.A. Aquaculture systems and practices: a selected review. United Nations Development Programme. FAO. Rome, 1989.

23. KANOWNIK W., WIŚNIOS M. Influence of carp breeding on physicochemical state of water in fish pond and receiver. Ecol. Eng. 44, 131, 2015 [In Polish].

24. FAO. The state of world fisheries and aquaculture. Sustainability in action. Rome, $\mathbf{2 0 2 0}$.

25. LASNER T., MYTLEWSKI A., NOURRY M., RAKOWSKI M., OBERLE M. Carp land: Economics of fish farms and the impact of region-marketing in the Aischgrund (DEU) and Barycz Valley (POL). Aquacult. 519, 734731, 2020.

26. RAFTOWICZ M., LE GALLIC B. Inland aquaculture of carps in Poland: Between tradition and innovation. Aquacult. 518, 734665, 2020.

27. ROY K., VRBA J., KAUSHIK S. J., MRAZ J. Nutrient footprint and ecosystem services of carp production in European fishponds in contrast to EU crop and livestock sectors. J. Clean. Prod. 270, 122268, 2020.

28. POKORNY J., HAUSER V. The restoration of fish ponds in agricultural landscapes. Ecol. Eng. 18 (5), 555, 2002

29. FRANCOVA K., SUMBEROVA K., JANAUER G.A., ADAMEK Z. Effects of fish farming on macrophytes in temperate carp ponds. Aquacult. Int. 27 (2), 413, 2019.

30. ADAMEK Z., MOSSMER M., HAUBER M. Current principles and issues affecting organic carp (Cyprinus carpio) pond farming. Aquacult. 512, 734261, 2019.

31. JAKUBIAK M., CHMIELOWSKI K. Identification of urban water bodies ecosystem services. Acta Sci. Pol. Formatio Circumiectus 19 (3), 73, 2020.

32. BOJARSKI B., SZCZERBIK P., LUDWIKOWSKA A. Ichthyofauna in streams on the UA Experimental Fisheries Station in Krakow. Komunikaty Rybackie 1 (132), 6, 2013 [In Polish].

33. POPP J., BEKEFI E., DULEBA S., OLAH J. Multifunctionality of pond fish farms in the opinion of the farm managers: the case of Hungary. Rev. Aquacult. 11 (3), 830, 2018

34. BUCZYŃSKA E., BUCZYŃSKI P., LECHOWSKI L., STRYJECKI R. Fish pond complexes as refugia of aquatic invertebrates (Odonata, Coleoptera, Heteroptera, Hydrachnidia): a case study of the pond complex in Zalesie Kańskie (central-east Poland). Nature Cons. 64, 39, 2007.

35. BOJARSKI B., LUDWIKOWSKA A., POPEK J., SZCZERBIK P., KLACZAK A., LUTNICKA H., POPEK W. Ichthyofauna and ecological role of pond canals of chosen fish farm. Komunikaty Rybackie 2 (139), 17, 2014 [In Polish].

36. WITKOWSKI A., KOTUSZ J., PRZYBYLSKI M. The degree of threat to the freshwater ichthyofauna of Poland: Red list of fishes and lampreys - situation in 2009. Chrońmy Przyrdę Ojczystą 65, 33, 2009. 
37. WITKOWSKI A. NOBANIS - Invasive Alien Species Fact Sheet - Pseudorasbora parva - Online Database of the European Network on Invasive Alien Species, www. nobanis.org, 07/05/2020, 2011.

38. PANICZ R., KESZKA S., RYBCZYK A., ZAWAL A. Molecular study of Prussian carp - an invasive species in the lakes of the Leszno Lakeland. Acta Biol. 23, 47, 2016.

39. GRABOWSKA J., KOTUSZ J., WITKOWSKI A. Alien invasive fish species in Polish waters: an overview. J. Verteb. Biol. 59 (1), 73, 2010.

40. NUNES A.L., TRICARICO E., PANOV V.E., CARDOSO A.C., KATSANEVAKIS S. Pathways and gateways of freshwater invasions in Europe. Aquat. Invas. 1, (4), 359, 2015.

41. RACZYŃSKA M., MACHULA S. The influence of carp ponds on the quality of waters of the river Krapiel (Western Pomerania). Infras. Ekol. Ter. Wiejs. 4 (2), 141, 2006.

42. NOWAK M., POPEK W., EPLER P. Range expansion of an invasive alien species, Chinese sleeper, Perccottus glenii Dybowski, 1877 (Teleostei: Odontobutidae) in the Vistula River drainage. Acta Ichthyol. Piscat. 38 (1), 37, 2008. 